\title{
Party All the Time: The CCP in Comparative and Historical Perspective
}

\author{
Patricia M. Thornton ${ }^{*}$
}

In The China Quarterly's first article on the Chinese Communist Party (CCP) in 1960, Franz Schurmann observed that despite having inherited "a huge land area, wracked by almost a half-century of war, a poverty-stricken population, disorganized masses of people, and the total collapse of government" in 1949, the CCP had succeeded in transforming the country into "one of the most powerful nations on the globe" during its first decade in power. ${ }^{1}$ Schurmann's assessment was arguably premature, but few would dispute it today as the Party enjoys its centenary and celebrates its eighth decade at the helm of what is now unquestionably a rising global superpower.

The Party's trajectory over the past 100 years has been nothing short of remarkable. When it was founded in Shanghai on 23 July 1921, with 13 members and the assistance of two Comintern advisors, the CCP comprised an informal network of young radical participants in local Marxist study groups hailing from six cities in eastern and central China. ${ }^{2}$ Their "disillusionment with utopian radicalism, and the anarchist philosophy that had inspired it," hardened over time into "an ideology of action." 3 Knowing relatively little about Leninism at the time, their innate predisposition towards both socialism and revolutionary voluntarism made them "instinctive" Leninists who saw the "masses" as hopelessly backward, and the prospect of revolution as impossible, without the robust intervention of an elite, militant leadership. ${ }^{4}$ A century later, the CCP boasts over 91 million members and continues to grow in size despite the decidedly more restrictive recruitment patterns and regimented disciplinary practices it has adopted under $\mathrm{Xi}$ Jinping 习近平. Its sheer size, unique historical trajectory and capacity to govern in the face of repeated challenges mark the $\mathrm{CCP}$ as one of the most successful political parties in history.

This special issue marking the centenary of the Party's establishment in 1921 looks back at its rise as it enters its second century of existence. Key to the Party's survival has been the adaptability of its institutions, the resilience of its practices and its capacity for innovation. At the same time, the CCP has acknowledged a history of sometimes catastrophic failures, as well as the

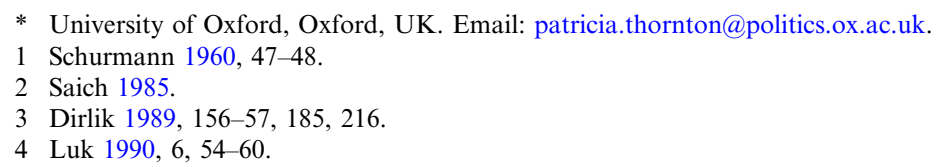


obstacles it continues to face, in successfully transforming itself from a "revolutionary" to a "ruling" party. Party documents detail efforts to address persistent internal fragilities and unanticipated external challenges. The contributors to this special issue document some of the institutions, practices and adaptations that have proved central to the CCP's growth and persistence, but they do not shy away from addressing some of the tests that lie ahead.

In this brief introduction, I consider the CCP in the broader context of comparative authoritarianism. I also review what many regard as the unique and exceptional features of the CCP's distinctive historical trajectory, highlighting the limits of the comparative framework in light of the extraordinary size and scope of the CCP's organization today.

I conclude with a brief consideration of how the Party under Xi Jinping has crafted the narrative of its own rise to power, the successes it wishes to highlight and the obstacles it anticipates encountering in what $\mathrm{Xi}$ is already referring to as the second of its "two centenaries." The Party continues to write and re-write its own history on terms very different from the ones set by observers and sometimes even by its most ardent admirers.

\section{Single-party Regimes in Comparative Perspective}

Almost by default, a centenary of the Chinese Communist Party dictates that it is worth considering how often Western scholarship has confidently predicted its imminent demise. Many heralded the fall of the Soviet Union in 1991 as the crest of democracy's "third wave," presaging a "terminal crisis in China within the next 10 to 15 years" that would inevitably lead to "the coming Chinese collapse." 5 Two years later, Francis Fukuyama proclaimed "the total exhaustion of viable systematic alternatives to Western liberalism," 6 and Ken Jowitt announced the "mass extinction" of the "Leninist 'regime-world' as a whole" and the "new world disorder" until a new global balance could be consolidated. ${ }^{7}$

But in 1999, Barbara Geddes demonstrated that single-party regimes, including those led by Leninist parties, had proved far more resilient and durable than other types of autocracies. ${ }^{8}$ She found that between 1946 and 1999, whereas military regimes had lasted nine years on average and strongman dictatorships had stayed the course for 15 years, single-party regimes had endured for an average of nearly 23 years. This difference was even more pronounced when she eliminated already defunct autocratic regimes from her dataset: the average age of either military or personalist regimes still in existence in 1998 was 7 and 19 years, respectively, whereas single-party regimes had endured for an average of 35 years. $^{9}$ A more recent study found that, as of 2006, one-party regimes were

5 Nathan 2003; Goldstone 1995.

6 Fukuyama 1989, 3.

7 Jowitt 1991, 11-13.

8 Geddes 1999.

9 Ibid., 131-32. 
the most common subtype of authoritarian rule, representing 57 per cent of nondemocracies; single-party states comprise fully a third of the total number of regimes across the globe. ${ }^{10}$ Furthermore, as Martin Dimitrov more recently points out, when compared to other nondemocracies, communist regimes are far and away the most resilient, outlasting both non-communist single-party regimes and nondemocratic monarchies by a wide margin. ${ }^{11}$

To what do single-party states, including communist regimes, owe their durability? Geddes proposed that single-party regimes prove more stable because their internal dynamics favour co-optation. In addition to distributing rewards to regime loyalists, single party-states exercise control over the allocation of educational opportunities, jobs and government posts. This control helps to ensure the acquiescence, if not the outright loyalty, of the most able, ambitious and upwardly mobile segments of society, particularly those whose opportunities for social mobility might otherwise be limited. ${ }^{12}$ Relying on official survey data, Bruce Dickson and Maria Rublee documented that as early as 1988, the average Party member in China earned 26.5 per cent more than the average non-Party member; and by 2010, Dickson found that for those seeking careers in the Party or state bureaucracies, Party membership was the key determinant in predicting career attainment and advancement, even when he controlled for education, age and gender. ${ }^{13}$ By dominating the societies over which they rule and vastly overpowering or eliminating rival bases of power, regime parties can develop remarkably efficient mechanisms for distributing benefits and resources on a selective basis.

Proposing that formal political institutions provide autocrats with a particularly valuable and stable mechanism for co-optation, Jennifer Gandhi and Adam Przeworski find that single-party regimes survived in power significantly longer than authoritarian leaders who permitted either no parties or multiple parties. The degree to which single-party regimes are capable of dominating and penetrating society further enables them to fine-tune policy concessions to potential challengers and to better modulate coercion and repression. Hegemonic party structures also help to contain and manage disputes among elites, providing potential challengers with guarantees that their interests are better served by supporting the party in power, even in times of crisis. ${ }^{14}$ Indeed, Victor Shih, Christopher Adolph and Mingxing Liu confirm that instead of aiming for the widest possible distribution of benefits under economic reform, post-Mao CCP leaders have relied on the cadre evaluation system to ensure social stability and fiscal income, but not necessarily to promote economic growth, thereby returning the highest payoffs to a relatively narrow elite coalition instead of to society at large. ${ }^{15}$

10 Magaloni and Kricheli 2010, 124.

11 Dimitrov 2013, 5.

12 Geddes 1999, 134.

13 Dickson and Rublee 2000, 100; Dickson 2014, 58.

14 Gandhi and Przeworski 2007.

15 Shih, Adolph and Liu 2012. 
Jason Brownlee's test of 135 authoritarian regimes between 1975 and 2000 confirms Geddes's findings on the durability of nondemocracies, but furthermore reveals that political parties bolster the endurance of both liberalized and unliberalized authoritarian regimes. When leaders co-opt or suppress elite rivals while defanging popular competitors early on, the ruling parties that emerge house robust coalitions capable of sustaining them in power over a longer duration. By contrast, if elite rivalries persist and challengers continue to maintain broad social support, the parties that emerge do not endure. His historical-institutional analysis conclusively demonstrates precisely how, for durable regime parties, the legacies of the past are imbricated with the politics of the present. ${ }^{16}$

\section{Party, Party-state or Something Else?}

Shortly after the 99th anniversary of the CCP's founding, the state-run Global Times seized the opportunity to point out that the CCP was so fundamentally different from Western political parties in terms of its scale, purpose and modes of operation that it ought not to be described as a "party" at all. Instead, pointing out that as the CCP continues to develop and remake itself, the editor concluded that there is no concept in the English language capable of truly capturing what, precisely, the CCP $i s .{ }^{17}$

Indeed, classic political science definitions regard both elections and electoral competition as central to what political parties do, ${ }^{18}$ making comparisons with authoritarian one-party systems problematic. Much of the earliest work in English on the CCP treats it as an example of a "totalitarian party," with a form and function fundamentally different from political parties in liberal democracies, but as nonetheless indispensable to the state, providing the direction, purpose and coordination it requires in order to function as a governing apparatus. ${ }^{19}$ Likewise, the state has proved critical to the survival of the Party: as Mao noted on the eve of founding the People's Republic in 1949, "our present task is to strengthen the people's state apparatus ... in order to consolidate national defence and protect the people's interests." 20 As Lily Tsai observes, the fact that the CCP benefits from the power and operation of one of the oldest state apparatuses in the world - "a benevolent dictatorship and developmental state like no other" - confers unique advantages for the Party. ${ }^{21}$

At the same time, the Party's relationship to the Chinese state is not necessarily a straightforward one, nor has it remained constant over time. Yongnian Zheng finds potent historical resonances in the Party's governing role, characterizing it as an "organizational emperor," the "reprogrammed or transformed product of

21 Tsai, Lily L. 2017, 296. 
Chinese imperial political culture," dominating both state and society. ${ }^{22}$ Unlike political parties that emerged as machines organizing electoral competition, in China the political party's main task was to first rebuild the state and, then, to selectively delegate power and managerial authority to state offices and bureaus. ${ }^{23}$ Shiping Zheng argues that insofar as the Party and the state are two political institutions with different organizational purposes and logics, the post-Mao Party remains the most fundamental obstacle to institutionalized state-building in China today. The post-revolutionary Chinese state "is more dependent on the CCP and less autonomous than an ideal type of modern state would suggest," particularly to the extent that it insists on infiltrating, managing and controlling all of the key offices and functions of the state apparatus. ${ }^{24}$ For Wang Hui, this process of infiltration and imbrication with the state has changed the nature of the CCP itself over time: with the elimination of ideological line-struggle at the end of the Cultural Revolution, the Party has gradually become "statified" and "an apparatus of depoliticized power" essentially indistinguishable from the state. Unmoored from its revolutionary class-based mission, it is rapidly devolving into part of a global "state-party" system. ${ }^{25}$ Kjeld Erik Brødsgaard concurs, arguing, however, that the CCP's shift from party-state to state-party under Xi Jinping represents a form of neo-socialism. He finds that whereas the proposed reform trends of the Deng Xiaoping 邓小平 era included the separation of the Party from the state and the state from business, under $\mathrm{Xi}$, "bidirectional entry and cross appointment" have become new watchwords. Party secretaries are increasingly taking on additional roles in the state apparatus and in state-owned enterprises, resulting in a new fusion of the orders of the Party and the state that Brødsgaard dubs a repoliticizing "state-party." 26

While also acknowledging the widespread practice of cross appointment between Party and state organizations, Holly Snape and Weinan Wang propose to jettison the concept of the party-state, arguing that it obfuscates more than it reveals. In its place, they propose a more nuanced disaggregation of the Party's formal and informal institutions and practices, ideology and discourse, and the multiplicity of actors actually engaged in the Party's work across society. Their model emphasizes understanding the complexity of the Party as it governs including paying careful attention to the multiple layers and dimensions of Party roles, and the multidirectional and multidimensional interplay between players and actors. As they point out, the CCP's separate identity "means that it cannot simply envelop the state and govern directly as the Party"; instead, its legitimacy requires it to "find a way to work via the state that results in effective governance." 27 Thus, in order to understand how the Party governs 
effectively, we must look both more broadly at the CCP over time as well as more narrowly as it governs in situ, both through - as well as alongside - the state.

\section{The Evolution of the CCP as a Regime Party}

In an oft-quoted 2003 article, Andrew Nathan attributed the CCP's surprising resilience in the wake of the 1989 Tiananmen crisis to its ability to reconsolidate and institutionalize itself. He cited the Party's increasingly norm-bound elite succession, meritocratic promotion patterns, the increased functional specialization, and the creation of participatory input institutions that bolstered the Party's legitimacy. Collectively, Nathan proposed, these factors had produced a uniquely Chinese form of "authoritarian resilience" capable of responding effectively to both internal and external shocks. ${ }^{28}$ David Shambaugh concurred, but he also proposed that this wave of institutionalization did not unfold in China despite the 1989 Tiananmen unrest and the collapse of Leninist party-states elsewhere, but because of it: the CCP undertook a systematic assessment of the causes of the collapse of other single-party regimes, and put sweeping reforms into place that arrested the process of atrophy then underway, completely overhauling its governing capacity. ${ }^{29}$ One such successful reform was Jiang Zemin's 江泽民 momentous 2001 decision to open Party membership to those it had previously targeted for struggle and elimination: private entrepreneurs. ${ }^{30}$ By co-opting these enterprising new social entrants, the CCP succeeded not only in neutralizing them as a potential threat to the Party but also in spawning a new hybrid class of "red capitalists" with close personal and political ties to the CCP, thereby ensuring that these social forces also had a stake in guaranteeing the health of the regime. $^{31}$

Others point to less formalized sources to explain the CCP's durability that extend beyond and persist in the interstices of the bureaucratic offices of the party-state. In contrast to the systematic and intentional process of adaptation described by Shambaugh, Kellee Tsai identified the myriad coping strategies of local actors attempting to evade restrictions or exploit opportunities as "adaptive informal institutions" in the existing political environment. ${ }^{32}$ Joseph Fewsmith goes ever farther, arguing that the apparent stability of the post-Mao CCP is owing not to institutionalization but to an elaborate but shifting system of formal and informal balances instead. ${ }^{33}$ Sebastian Heilmann and Elizabeth Perry argued that the CCP's experimentalist tradition of "maximum tinkering," which evolved of necessity during the deprivations of the civil war period, gave rise to a flexible

28 Nathan 2003; although note Fewsmith's more recent critique in Fewsmith and Nathan 2019, as well as Fewsmith's contribution to this special issue.

29 Shambaugh 2008.

30 Ibid.

31 Dickson 2003.

32 Tsai, Kellee S. 2006.

33 Fewsmith 2021. 
"guerrilla policy style" capable of producing new discoveries and novel solutions to existing problems. This distinctive tradition spawned a set of uniquely adaptive practices wedded to the CCP's avowedly Leninist organizational framework. ${ }^{34}$ More recently, Vivienne Shue reaches even further back in history to illustrate the ways in which the CCP has "reappropriated and deployed some of the defining modalities of the imperial polity, even as it also spoke the language of the nation." 35 Early Party leaders superimposed the mantle of a unitary state structure atop the remains of the vast multi-ethnic empire of the Qing, such that "presentation, negotiation, and intermediation through a range of situated idioms and systems of value have remained robust components in the unitary state's practice, where required, even in the present-day technocracy that is the PRC party-state." She reminds us that the "template of governance under empire" not only endures in Xi Jinping's China, but that it "remains a defining component in the basic grammar of Chinese governance today." 36

\section{The CCP: Early Origins, Contradictions and Contemporary Adaptations}

The authors contributing to this special issue each consider the multiple and open-ended processes of development, adaptation and change that have shaped the first hundred years of the CCP's existence, both before and after the founding of the state. Implicit in this project is the realization that, like the institutions of the state and Party themselves, such processes of change are not necessarily unidirectional, but multi-layered and complex. Instead, the multiple and intertwining shifts in both Party and state might be best understood as "an ornate tracery of interlacing flows, traveling at different speeds over uneven spaces and across time." 37 Despite the triumphalist narrative the contemporary leadership projects, what the historical record shows is that the CCP has been defined and sometimes constrained - by its earliest organizational commitments and practices. It continues to be challenged from within and without by persistent contradictions, even as it demonstrates a truly remarkable capacity for adaptation and innovation.

In the first section, four authors consider how the CCP's earliest commitments and practices continue to exert their particular pull on the Party today. Pre-dating the establishment of the Party itself, Rebecca Karl reminds us, was the promise and the peril of revolutionary organization and mobilization in early Republican China. Qu Qiubai’s 篗秋白 concept of comradeship, “as a collectively-envisioned future-oriented possibility of social organization actively pursued in the present through horizontal relationality," proved central to the Bolshevization of the early CCP. She finds that comradeship "cleared a

37 Shue and Thornton 2017, 20. 
horizontal possibility for political work, while also imposing a vertical relationship" and an affective tie between the Party and its members. Xi Jinping's 2016 exhortation to CCP members to resuscitate the habit of hailing each other as "comrades" has fallen flat in part because the contemporary Party's political commitments reinforce verticality, hierarchy and quiescence, instead of invoking the egalitarian political relations to which comradeship aspires.

The CCP's techniques of horizontal relationality - whether aspirational or actual - have extended beyond the narrow confines of the Party to include the equally assiduous cultivation of "affective sovereignty." Christian Sorace's contribution describes the myriad ways that the party-state claims sovereign jurisdiction over people's emotional life. The Mao-era Party sought to build a new emotional landscape for citizens by inculcating "class feelings" among them, stressing not only comradeship within the ranks of the people but also sowing enmity between the revolutionary masses and designated class enemies. In more recent times, the CCP's "emotion work" has focused on the cultivation of "positive energy" and the public performance of gratitude towards the Party. Gratitude discourse is ubiquitous along the borderland regions where ethnic minorities are numerous, including among the Uyghurs in Xinjiang, highlighting the ease with which gratitude has come to stand in for compliance.

Horizontal relationality has long been offset by the strength of vertical authority structures within the Party. Democratic centralism is a core CCP commitment that, in theory, pulls the Party in both directions. Patricia Thornton demonstrates how it has been successively refashioned as a constitutionally enshrined principle, an established political practice and, most recently, as a tool of the increasingly sharp-edged disciplinary system. The remaking of democratic centralism is suggestive of the Party's adaptiveness and institutional plasticity. But it also serves as a potent reminder of the CCP's enduring illiberal constitutionalism. With Xi demanding "correct and effective" democratic centralism, performing not only one's acquiescence to collective discipline but also enthusiastic loyalty to the centre is a way of shoring up one's political survival.

Compliance with shifting Party goals at the grassroots of society has been carried out by work teams, a distinctive CCP governing practice that has persisted to the present day. As Elizabeth Perry notes, work teams have served a dual function for the Party by harnessing the enthusiasm and expertise of students and intellectuals to carry out important tasks at the social grassroots and also by co-opting highly educated and idealistic elites who might otherwise have challenged the regime, as occurred in the former Soviet Union and East European Leninist regimes. Instead, under Xi Jinping, young faculty members have been volunteering to serve as "first secretaries" of work teams tackling poverty and corruption in rural China, thereby demonstrating the sincerity of their commitment to Xi's signature agenda and, more broadly, the Party's mission.

The four papers in the second section elaborate on some of the contradictions that characterize, or arguably even drive, CCP governance, both historically as well as currently. Harriet Evans reflects on how the Party's early commitments 
to both gender and socioeconomic equality have shaped the life experience of largely underprivileged women in one neighbourhood in Beijing's old "South City" (nan cheng 南城). Her ethnographic work among low-income, femaleheaded households in Dashalar shows that despite greater access to education and employment not enjoyed by previous generations, the values and practices associated with patriarchal beliefs persist. Evans documents how these conflicting values coexist as a kind of "patchy patriarchy" among working-class women, highlighting the unevenness of the CCP's ability to penetrate, or perhaps to alter, the social grassroots over time.

Likewise, Iza Ding and Mike Thompson-Brusstar consider the enduring legacies of the CCP's pre-revolutionary disdain for the "feudal bureaucracy" spawned by its predecessors. Ideologically committed to the building of a radically new political system, the CCP is nonetheless rent by internal contradictions, "perpetually pinned between the desiderata of state-building and state-breaking, of regulation and revolution, of rationality and morality, of expertise and loyalty, of institutional capacity and political purity." Their analysis of official discourse in the People's Daily from 1949-2020 uncovers "an anti-bureaucratic ghost [that] dwells in the machinery of China's bureaucratic state," which continues to generate thorny contradictions in present-day CCP governance.

In a somewhat similar vein, Ewan Smith counterintuitively draws on the Party's own theory of rules to interrogate prevailing assumptions regarding the CCP's institutionalization and resilience. The general scholarly view assumes that the Party's stable consensus concerning its own operating norms was dismantled over the course of the Mao era and destroyed during the Cultural Revolution, before being rebuilt in the post-Mao period in the drive towards "institutionalization, standardization and proceduralization” (zhiduhua 制度化, guifanhua 规范化, chengxuhua 程序化). Lacking a mechanism to distinguish between Party and state rules, Smith points out that the CCP is unable to legitimate or enshrine the practical force of its conventions, thus ultimately undermining its capacity to institutionalize over the longer term.

Wen-Hsuan Tsai and Xingmiu Liao examine the Party's cultivation and oversight of the Communist Youth League, which has successively served as an interest group, a cadre "conveyor belt" to replenish the Party, and a United Front agency focusing on youth. However, the post-Mao Party has been left without a reliable "reserve army" of cadres with which to replenish itself, a situation not dissimilar to the one in which the CCP found itself in the years before Mao's death. Xi Jinping, who does not have a close personal connection with the league, has reduced its role while augmenting his own personal power through centralization. Yet having marginalized this once important talent pool, the CCP now faces the challenge of establishing new recruitment mechanisms even as its current cohort is rapidly nearing retirement age.

The five papers in the final section highlight new and emerging adaptations in the CCP's development under Xi Jinping. Xi's address to the 19th Party Congress asserting the paramount position of the CCP - "north, south, east, and west - the 
Party is leader of all" - has indeed marked a new level of Party control over grassroots organizations, village cadres and in industries in both the private and state-owned sectors of the economy. Yet as the final contribution reminds us, when we look closer into those elements that appear to confer both stability and resilience, we instead find a more tenuous set of arrangements. As the Party's swift realignment around $\mathrm{Xi}$ Jinping as the "core" attests, the post-Mao Party has not replaced its less formalized, and therefore potentially fragile, practices of power sharing with more enduring rational-legal institutions.

Village cadres have long played a crucial role in the post-revolutionary Chinese party-state but have often proved difficult to discipline and control. As Juan Wang and Yu Mou point out, prior to 2018, Party discipline rules did not apply to non-Party cadres at the grassroots, and their position vis-à-vis formal legal frameworks was ambiguous. This anomaly has been transformed under $\mathrm{Xi}$ Jinping, and they are now formally fully subject to both Party rules and state law as "public agents." By carrying out an extensive campaign to clean up both village administration and elections, the Party under $\mathrm{Xi}$ has greatly expanded its reach, adapting grassroots governing practices by increasing its control over these agents of the party-state at the interface with village society.

Contrary to claims that $\mathrm{Xi}$ has ushered in a new era of enhanced Party control over what was previously a reforming state-owned sector of the economy, Sarah Eaton and Wendy Leutert find a high degree of goal continuity with the preceding $\mathrm{Hu}$ administration, but strikingly different governance approaches. $\mathrm{Xi}$ Jinping has considerably amplified Party authority by subordinating the government apparatus to the Party, strengthening Party organizations, deploying the cadre management system to control leadership rotations, and overseeing an increasing reliance on "managed campaigns." Although the Xi administration links greater Party control to improved enterprise efficiency and performance, decreased enterprise autonomy entails risks and may drive down performance. International concerns about Party control have already prompted stronger screening mechanisms for foreign direct investment by the US and the European Union, resulting in increased tensions that are likely to have a dampening effect on economic performance in the state-owned sector in the months and years to come.

With respect to domestic and foreign companies in the private sector, Daniel Koss documents the impact of the ongoing Party-building drive that has been gaining strength since 2000, when Huawei likely became the first private firm to establish not merely a Party cell but a fully-fledged CCP committee. Since that time, organization departments have deployed literally hundreds of thousands of Party-building coaches in the private sector to spearhead the effort. As a result, enterprise-level CCP branches are increasingly taking on a broader range of functions, from monitoring policy compliance to attempting to influence enterprise management decisions. As Koss's contribution shows, newly refashioned Party branches have become key cogs in the machinery driving Xi's 
"Chinese dream" of national rejuvenation, although he notes mixed effects on company performance.

But what do these new Party organizations actually do? How do they function? Chris Mittelstaedt's contribution focuses on the Party's management of its members through mandated monthly "Thematic Party Days" (TPDs), a recent adaptation that has quickly become a fixture of CCP branches' organizational life under Xi Jinping. Unlike the majority of Party branch activities during the Mao era, TDPs are diverse, integrated and varied, and allow limited room for individual branches to choose and shape topics around local interests or needs, although diversity is conditional on the overt acceptance of the Party's ideological supremacy. Mittelstaedt finds that although heightened exposure to the Party's narratives, slogans and documents during TPDs may not transform all members into true believers, the TPDs are sufficient to bind the grassroots to the Party centre by means of practice.

Finally, one of the persistent misinterpretations of the post-Mao era is that institutionalization has signalled the end of strongman politics in China, and thereby has produced a more stable and routinized period of Party rule. However, Joseph Fewsmith argues instead that the CCP has never actually "institutionalized." The relatively greater level of stability achieved in the post-Mao period has been accomplished through the balancing of countervailing political factions and interests within the Party elite. It is this informal system of "checks and balances," he maintains, that has contributed to a relatively stable equilibrium in the Party from the Deng period forward. He warns that this has also produced competing bureaucracies, divided along factional lines, which intermittently surface as a source of fragility for the regime and could well prove destabilizing to the Party and state moving forward.

\section{The CCP's "Two Centenaries"}

Since Xi Jinping became general secretary of the CCP in 2012, a great deal of attention has been paid to his Stalinesque accumulation and centralization of political power, with alarm bells repeatedly sounding over the "cult of personality" he is said to be building. ${ }^{38}$ As the articles in this issue demonstrate, the CCP under Xi has increased its oversight and control of state-owned enterprises, the state apparatus and the private sector of China's expanding economy. It has publicly downplayed its heavy recruitment of urban elites, university graduates and captains of industry in recent years. Instead, it has attempted to foreground its ongoing appeals to those within its traditional core constituencies and continues to exhort its members to "never forget the Party's original mission." At the same time, it has also slowed the growth of the number of new entrants, limiting access to the Party ostensibly as a way of maintaining its status as an elite vanguard organization. 
But this is not the story that the CCP tells of its first one hundred years. In preparation for the centenary, the Central Propaganda Department released an updated edition of A Brief History of the Chinese Communist Party that reflects a version of the Party's past, present and future for popular consumption, and specifically for study during the ongoing Party history education campaign. The 2021 revision was a year in the making and involved consultation with 11 central ministries and more than 50 Party committees to ensure the propagation of "the correct view of history." 39 In the newly updated version, some of the more problematic elements of the not-too-distant past that have disappeared from the Party's rear-view mirror have been replaced with narratives designed to project "positive energy" about the CCP. For example, whereas earlier editions of $A$ Brief History summed up the painful struggles of the 1957 Anti-Rightist Campaign and the subsequent Great Leap Forward of 1958 by warning readers not to forget these "bitter historical lessons," the 2021 edition omits the injunction. As late as 2001, A Brief History devoted an entire chapter to the Great Proletarian Cultural Revolution, entitled: "The civil strife of the tenyear 'Cultural Revolution'," clearly and unequivocally naming Mao Zedong as its initiator, reproducing the official Party verdict on the Cultural Revolution as set down by the 1981 "Resolution on certain questions concerning the history of the Party since the founding of the People's Republic." The 2021 edition replaces the older chapter with an anodyne discussion entitled "Exploration and tortuous developments in the building of socialism," which omits the details of the 1981 verdict. Also now missing is Deng Xiaoping's famous 1989 warning against hinging "the fate of a nation on the reputation of one or two people," although Deng's remark that every generation produces a "core" leader that the Party must protect has been retained. ${ }^{40}$

Even more significant, of course, will be the third resolution on Party history, scheduled for the 19th Central Committee's Sixth Plenum. Early reports suggest that the continuation of "struggle" will be a key theme, and that what Xi has dubbed "the great rejuvenation of the Chinese nation" will depend upon the absolute loyalty of the Party's membership to both its "line" and its "core." 41

However, if we proceed from the starting point that the CCP is, or ever has been, just "one thing, wedded to a single dogma and a set way of doing things" 42 - in other words, a singular, internally homogenous agent of history - then we invariably lose sight of its incredibly complex and multifaceted nature across space and time. Xi Jinping's "grand narrative" may have the virtue of projecting a certain centralized coherence to the Party's invariably triumphalist narrative, but it elides the far more interesting, localized and lived realities of the Party

39 Sun 2021.

40 Wong and Zhai 2021

41 Wu 2021; Deng 2021.

42 Cheek, Mühlhahn and van de Ven 2021, 5. See also my review essay, "Through the mirror of CCP history: four perspectives," in this special issue. 
in the making, which the various contributions in this special issue have attempted to capture.

\section{Biographical note}

Patricia M. THORNTON is an associate professor of political science at the University of Oxford, and tutor in the politics of China at Merton College.

\section{Acknowledgements}

I wish to thank all of the contributors to this special issue, and the many anonymous reviewers, who gave of their time and energy; but especially Tim Pringle, the editor of The China Quarterly, and the editorial staff, Raphael Jacquet and Rowan Pease, whose time, energy, patience and expertise made this project possible.

\section{Conflicts of interest}

None.

\section{References}

Brødsgaard, Kjeld Erik. 2018. "China's political order under Xi Jinping: concepts and perspectives." China: An International Journal 16(3), 1-17.

Brownlee, Jason. 2007. Authoritarianism in an Age of Democratization. Cambridge: Cambridge University Press.

Cassinelli, Charles W. 1962. "The totalitarian party.” The Journal of Politics 24(1), 111-141.

Cheek, Timothy, Klaus Mühlhahn and Hans van de Ven. 2021. The Chinese Communist Party: A Century in Ten Lives. Cambridge: Cambridge University Press.

Deng, Yuwen. 2021. "Xi Jinping weihe yao zuo di san fen lishi jueyi” (Why Xi Jinping seeks to pass a third historical resolution). Deutsche Welle, 6 September, https://p.dw.com/p/3zylH. Accessed 19 October 2021.

Dickson, Bruce J. 2003. Red Capitalists in China: The Party, Private Entrepreneurs, and Prospects for Political Change. Cambridge: Cambridge University Press.

Dickson, Bruce J. 2014. "Who wants to be a communist? Career incentives and mobilized loyalty in China." The China Quarterly 217, 42-68.

Dickson, Bruce J., and Maria Rost Rublee. 2000. "Membership has its privileges: the socioeconomic characteristics of Communist Party members in urban China." Comparative Political Studies 33(1), $87-112$.

Dimitrov, Martin. 2013. "Understanding communist collapse and resilience." In Martin Dimitrov (ed.), Why Communism Did Not Collapse. Cambridge: Cambridge University Press, 3-39.

Dirlik, Arif. 1989. The Origins of Chinese Communism. Oxford: Oxford University Press.

Fewsmith, Joseph. 2021. Rethinking Chinese Politics. Cambridge: Cambridge University Press.

Fewsmith, Joseph, and Andrew J. Nathan. 2019. "Authoritarian resilience revisited: Joseph Fewsmith with response from Andrew J. Nathan.” Journal of Contemporary China 28(116), 167-179.

Fukuyama, Frances. 1989. "The end of history?" The National Interest 16, 3-18.

Gandhi, Jennifer, and Adam Przeworski. 2007. "Authoritarian institutions and the survival of autocrats." Comparative Political Studies 40(11), 1279-1301.

Geddes, Barbara. 1999. "What do we know about democratization after twenty years?" Annual Review of Political Science 2(1), 115-44. 
Goldstone, Jack A. 1995. "The coming Chinese collapse." Foreign Policy 99, 35-53.

Heilmann, Sebastian, and Elizabeth J. Perry. 2011."Embracing uncertainty: guerrilla policy style and adaptive governance in China." In Elizabeth J. Perry and Sebastian Heilmann (eds.), Mao's Invisible Hand: The Political Foundations of Adaptive Governance in China. Cambridge, MA: Harvard University Asia Center, 1-29.

$\mathrm{Hu}$, Xijin. 2020. "Zhongguo gongchandang shi shei? Huashengdun gai bu zhe tang ke" (Who is the Chinese Communist Party? Washington should take this class). Huanqiu shibao, 18 July 2020, https://opinion.huanqiu.com/article/3z60WySQZwI. Accessed 10 December 2020.

Jowitt, Ken. 1991. "After Leninism: the new world disorder." Journal of Democracy 2(1), 11-20.

Luk, Michael Y.K. 1990. The Origins of Chinese Bolshevism: An Ideology in the Making, 1920-1928. Oxford: Oxford University Press.

Magaloni, Beatriz, and Ruth Kricheli. 2010. "Political order and one-party rule." Annual Review of Political Science 15(13), 123-143.

Mao, Zedong. 1949. "On the people's democratic dictatorship: in commemoration of the twenty-eighth anniversary of the Communist Party of China." Available at https://www.marxists. org/reference/archive/mao/selected-works/volume-4/mswv4_65.htm.

Nathan, Andrew J. 2003. "China's changing of the guard: authoritarian resilience." Journal of Democracy 14(1), 6-17.

Pei, Minxin. 2021. "China: totalitarianism's long shadow." Journal of Democracy 32(2), 5-21.

Saich, Tony. 1985. "Through the past darkly: some new sources on the founding of the Chinese Communist Party." International Review of Social History 30(2), 167-182.

Sartori, Giovanni. 1976. Parties and Party-systems: A Framework for Analysis. Cambridge: Cambridge University Press.

Schurmann, H.F. 1960. "Organisational principles of the Chinese communists." The China Quarterly $2,47-58$.

Shambaugh, David. 2008. China's Communist Party: Atrophy and Adaptation. Berkeley, CA: University of California Press.

Shih, Victor, Christopher Adolph and Mingxing Liu. 2012. "Getting ahead in the Communist Party: explaining the advancement of Central Committee members in China." American Political Science Review 106(1), 166-187.

Shue, Vivienne. 2018. "Party-state, nation, empire: rethinking the grammar of Chinese governance." Journal of Chinese Governance 3(3), 268-291.

Shue, Vivienne, and Patricia M. Thornton. 2017. "Introduction: beyond implicit political dichotomies and linear models of political change in China." In Vivienne Shue and Patricia M. Thornton (eds.), To Govern China: Evolving Practices of Power. Cambridge: Cambridge University Press, 1-26.

Snape, Holly, and Weinan Wang. 2020. "Finding a place for the Party: debunking the 'party-state' and rethinking the state-society relationship in China's one-party system." Journal of Chinese Governance 5(4), 1-26.

Sun, Yeli. 2021. "Xue dangshi, wu sixiang, shou jiaoyu de xian huo jiaocai" (A fresh and lively text for studying Party history, comprehending thought and getting educated). Renmin wang, 17 March, http://paper.people.com.cn/rmrb/html/2021-03/17/nbs.D110000renmrb_10.htm.

Tsai, Kellee S. 2006. "Adaptive informal institutions and endogenous institutional change in China." World Politics 59(1), 116-141.

Tsai, Lily L. 2017. "Bringing in China: insights for building comparative political theory." Comparative Political Studies 50(3), 295- 328.

Wang, Hui. 2006. "Depoliticized politics, multiple components of hegemony, and the eclipse of the sixties." (Christopher Connery (trans.)). Inter-Asia Cultural Studies 7(4), 683-700.

Wong, Chun Han, and Keith Zhai. 2021. "China repackages history in support of Xi's vision." The Wall Street Journal, 16 June, https://www.wsj.com/articles/china-repackages-history-xi-propagandacommunist-party-centenary-11623767590. 
Wu, Wei. 2021. "Shijiu jie liu zhong quanhui 11 yue zhaokai, zhongdian yanjiu quanmian zongjie zhongda chengiiu he lishi jingyan" (The 19th Central Committee's Sixth Plenary is to be held in November and will focus on the comprehensive study of [the Party's] major achievements and historical experience). Xinjing bao, 31 August, https://news.sina.com.cn/c/2021-08-31/doc-iktzqtyt3297855. shtml. Accessed 19 October 2021.

Zheng, Shiping. 1997. Party vs. State in Post-1949 China: The Institutional Dilemma. Cambridge: Cambridge University Press.

Zheng, Yongnian. 2009. The Chinese Communist Party as Organizational Emperor: Culture, Reproduction, and Transformation. London: Routledge. 